\title{
Індивідуалізований підхід у сучасному лікуванні гемофілії А
}

\author{
А.Р. Хиць \\ Редакція журналу «Український медичний часопис»
}

15 жовтня 2020 р. відбувся медичний телеміст Україна - Польща на тему «Персоналізований підхід в сучасному лікуванні гемофілії А», спікерами якого виступили Олександра Стасишин, доктор медичних наук, провідний науковий співробітник дУ «Інститут патології крові та трансфузійної медицини Національної академії медичних наук (НАМН) України» (Львів, Україна), Катерина Вільчевська, кандидат медичних наук, завідувач Центру патології гемостазу Національної дитячої спеціалізованої лікарні МОз України «Охматдит», завідувач відділу гематології ДУ «Інститут невідкладної та відновлювальної хірургії імені В.К. Гусака НАМН України» (Київ, Україна), та Томаш Урасіньскі (Tomasz Urasiński), професор кафедри педіатрії, онкогематології та гастроентерології Поморського медичного університету у Щецині (Польща).

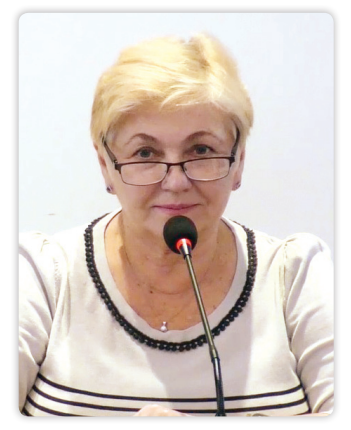

Перший спікер заходу Катерина Вільчевська виступила з доповіддю «Важливість індивідуалізованого підходу в лікуванні дітей з гемофілією А». Гемофілія - спадкове X-зчеплене захворювання системи гемостазу, що характеризується зниженням або порушенням синтезу факторів згортання крові (ФЗК): VIII (FVIII) при гемофілії типу A, IX (FIX) - В. Клінічно гемофілія проявляється спонтанними тривалими кровотечами у м'язи та суглоби. Основний принцип лікування хворих на гемофілію - адекватна замісна гемостатична терапія концентратами ФЗК, так звана факторна терапія. Однак, незважаючи на суттєві досягнення у лікуванні пацієнтів із гемофілією, і досі залишається проблемним питання розвитку ускладнень, пов'язаних із лікуванням. Так, факторна терапія супроводжується ризиком розвитку інгібіторної форми гемофілії [1].

Тяжкість клінічного перебігу гемофілії залежить від ступеня недостатності коагуляційної активності ФЗК. Залежно від клінічних проявів гемофілії, ії класифікують на три форми: легку, середньої тяжкості та тяжку (табл. 1) [2]. Наявні дані свідчать, що із загальної кількості пацієнтів з гемофілією до 85\% - із гемофілією А, 3 яких 60-70\% мають тяжку форму. Тяжка форма гемофілії супроводжується спонтанними сильними кровотечами у суглоби та м'язи. Навіть одна кровотеча може бути пов'язана із ризиком для життя. Так, дані літератури свідчать, що при одноразовому інтракраніальному крововиливі ризик летального кінця становить 20\% [3]. У структурі геморагічних проявів при гемофілії найчастішим $\epsilon$ гемартроз, який запускає каскад біологічних реакцій, що можуть призвести до розвитку прогресуючої деструкції суглоба та в результаті - до деформуючої артропатії. Клінічні дані свідчать, що навіть незначна кількість кровотеч в один і той самий суглоб може впливати на ураження опорно-рухового апарату з розвитком незворотних прогресуючих структурних змін у суглобі [4]. У дослідженні M.B. Funk та співавторів (2002) на прикладі 15 пацієнтів із гемофілією продемонстровано, що кількість суглобових кровотеч напряму пов'язана з ураженням суглобів. Так, 3-4 гемартрози на рік значно погіршують якість життя дітей з гемофілією та можуть спричинити ранню інвалідизацію. При цьому якість життя пацієнтів із гемофілією, що не мають жодної кровотечі протягом року, практично відповідає такій у пацієнтів без гемофілії [5].

Відповідно з метою запобігання розвитку кровотеч у паці$\epsilon$ ттів із гемофілією показана профілактична терапія, що характеризується введенням препаратів «заздалегідь» (табл. 2). Історія впровадження профілактичної терапії до клінічної практики лікування пацієнтів із тяжкою формою гемофілії починає свій відлік з 1976 р., коли у Швеції вперше застосовано цей підхід.
Із 1990 р. профілактична терапія впроваджена як терапія першої лінії дітей з тяжкою формою гемофілії, а з початку 2000-х років профілактичну терапію почали впроваджувати і для лікування дорослих пацієнтів [6, 7]. Сьогодні профілактична терапія - загальновизнаний стандарт лікування дітей із тяжкою формою гемофілії. Для оптимізації результатів лікування пацієнтів із гемофілією основною метою терапії повинно бути:

- запобігання кровотечам і розвитку хронічної артропатії та больовому синдрому;

- покращення якості життя;

- зниження довгострокових соціальних затрат.

Будь-яку профілактику, що розпочалася після множинних кровотеч, необхідно розглядати як вторинну. Профілактична терапія суттєво покращує довгостроковий клінічний прогноз порівняно з лікуванням «за вимогою». Результати проспективного відкритого рандомізованого контрольованого дослідження SPINART продемонстрували, що вторинна профілактика знижує частоту гемартрозів на 93\% порівняно з лікуванням «за потребою» [8]. Відповідно до сучасних рекомендацій безпеку терапії слід оцінювати за результатами тривалих спостережень

Таблиця 1 Ступені тяжкості гемофілії залежно від активності ФЗК Класифікація гемофілії за ступенем тяжкості

\begin{tabular}{lcl}
\hline $\begin{array}{c}\text { Ступінь } \\
\text { тяжкості }\end{array}$ & $\begin{array}{c}\text { Активність } \\
\text { фактора }\end{array}$ & \multicolumn{1}{c}{ Клінічна картина } \\
\hline Тяжкий & $<1 \%$ & Спонтанні кровотечі, переважно в суглоби і м'язи \\
\hline $\begin{array}{l}\text { Середньо- } \\
\text { тяжкий }\end{array}$ & $>1-\leq 5 \%$ & $\begin{array}{l}\text { Можливі спонтанні кровотечі } \\
\text { Сильна кровотеча при травмі чи хірургічному втручанні }\end{array}$ \\
\hline Легкий & $>5-<40 \%$ & $\begin{array}{l}\text { Сильна кровотеча при серйозній травмі чи хірургічному } \\
\text { втручанні }\end{array}$ \\
\hline
\end{tabular}

Таблиця 2 Види профілактичної терапії

\begin{tabular}{|c|c|}
\hline \multicolumn{2}{|r|}{ Профілактична терапія } \\
\hline $\begin{array}{c}\text { Вид } \\
\text { профілактики }\end{array}$ & Характеристика \\
\hline Первинна & $\begin{array}{l}\text { - Запобігання розвитку артропатій або кровотеч, що загрожують життю; } \\
\text { • починається до розвитку будь-якого ушкодження суглоба, } \\
\text { до 2-річного віку та хоча би до 2-го епізоду кровотечі }\end{array}$ \\
\hline Вторинна & $\begin{array}{l}\text { • Зниження частоти кровотеч у суглоби-мішені, прогресування } \\
\text { артропатій та кровотеч, що загрожують життю; } \\
\text { • розпочинається після початкового ушкодження суглоба чи серйозної } \\
\text { кровотечі }\end{array}$ \\
\hline Третинна & $\begin{array}{l}\text { - Призупинення клінічних симптомів артропатії та запобігання іншим } \\
\text { ускладненням; } \\
\text { • починається в дорослому віці для запобігання кровотечам, } \\
\text { що загрожують життю, та для зменшення прогресування вже наявної } \\
\text { артропатії }\end{array}$ \\
\hline
\end{tabular}


у реальній клінічній практиці, тоді як оцінку ефективності рекомендовано проводити за такими показниками:

- річна кількість кровотеч на 1 пацієнта;

- річна кількість гемартрозів на 1 пацієнта;

- частка пацієнтів із річною кількістю кровотеч <1.

Фактори, що впливають на вибір терапевтичного підходу:

- базовий рівень активності ФЗК;

- фенотип кровотечі;

- розуміння пацієнтом/батьками дитини з гемофілією значущості регулярного лікування та готовності виконувати рекомендації лікаря;

- можливість пацієнта/батьків дитини з гемофілією навчитися техніці введення препарату ФЗК;

- наявність препарату ФЗК у достатній кількості.

Для захисту від кровотеч всім пацієнтам із гемофілією рекомендоване призначення замісної профілактичної терапії препаратом ФЗК. Такий підхід суттєво покращить довгостроковий клінічний прогноз порівняно з лікуванням «за вимогою».

Переваги профілактичної терапії:

- зниження частоти кровотеч і виникнення артропатій порівняно з лікуванням «за вимогою»;

- зниження потреби у госпіталізації та ортопедичних хірургічних втручаннях, поліпшення відвідування школи і роботи, стимулювання успішності й досягнень дає можливість повноцінно брати участь у професійній діяльності та відпочинку.

Профілактична терапія не лише дозволяє значно знижувати частоту кровотеч і запобігає артропатії, але й підвищує якість життя і покращує соціалізацію пацієнтів. Індивідуалізована профілактика сприяє підвищенню прихильності пацієнта до терапії, дозволить контролювати фармакокінетичні параметри, зокрема періоди, коли активність ФЗК знижується <1, а також проводити фармакокінетично обґрунтовану корекцію терапії. Таким чином, Всесвітня організація охорони здоров'я, Всесвітня федерація гемофілії ї (World Federation of Hemophilia - WFH) та національні організації багатьох країн схвалили призначення ранньої профілактичної терапії як стандарт лікування дітей із тяжкою формою гемофілії та рекомендують продовження профілактичної терапії у дорослому віці [9].

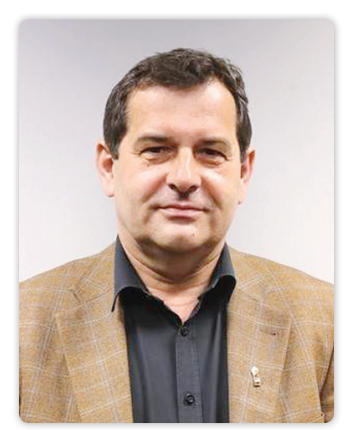

Професор Томаш Урасіньскі виступив $з$ доповіддю «Практичні аспекти застосування індивідуалізованого підходу в лікуванні хлопчиків із тяжкою гемофілією А в Польщі». Як вже зазначила у свій доповіді К. Вільчевська, за ступенем тяжкості гемофілію прийнято класифікувати на легку, середньої тяжкості та тяжку. Легка форма гемофілії характеризується активністю FVIII у межах 5-50\%. Відповідно нормальним вважають рівень гемостазу, де активність ФЗК становить 50-150\% [10]. У Польщі профілактичну терапію пацієнтів із гемофілією А розпочали у 2008 р., і сьогодні клінічні результати профілактики свідчать на користь регулярного введення концентратів FVIII у дозі 25-40 Од./кг маси тіла 3 рази на тиждень. Крім того, про вплив профілактики на зниження частоти кровотеч свідчать і міжнародні товариства. Так, у останніх рекомендаціях WFH 2020 р. зазначено, що регулярне введення гемостатичних препаратів з метою запобігання кровотечам у людей з гемофілією дозволяє їм вести активний спосіб життя з нормальною якістю життя, зіставною з такою в осіб без гемофілії. На користь ефективності профілактики вказують результати міжнародних досліджень. Так, у рандомізованому клінічному дослідженні A. Gringeri та співавторів (2011) підтверджена ефективність профілактичної терапії у запобіганні кровотечам і артропатіям у дітей із гемофілією, зокрема у разі маніфестації захворювання в ранньому дитинстві [11].

Загальноприйнятим варіантом профілактичного лікування $\epsilon$ введення препарату FVIII в дозі 20-40 Од./кг 3-4 рази на тиж- день, однак це не завжди забезпечує належний клінічний ефект. Це пов'язано з тим, що двох однакових пацієнтів не буває і кожний пацієнт має низку індивідуальних характеристик, включно з віком, способом життя, масою тіла, фенотипом кровотечі, рівнем фізичної активності, ураженням суглобів, прихильністю до терапії та індивідуальною фармакокінетичною відповіддю на введення FVIII. Таким чином, усі пацієнти з гемофілією потребують оптимізації профілактичної терапії, оскільки однакове дозування препаратів ФЗК відповідно до маси тіла зазвичай неефективне для більшості пацієнтів. У цьому разі доцільним $\epsilon$ застосування індивідуалізованого підходу до профілактичної терапії, який включає такі вимоги для кожного окремого пацієнта:

- період життя;

- рівень фізичної активності;

- фенотип (частота і тип) кровотечі;

- фармакокінетика ФЗК [12].

Фармакокінетика - розділ фармакології, що вивчає шляхи надходження препарату в організм, його абсорбцію, розподіл, метаболізм, кліренс. Визначення фармакокінетики ФЗК дозволяє з'ясувати, які зміни активності фактора, пов'язані з часом, відбуваються після його внутрішньовенного введення. Тобто фармакокінетика ФЗК полягає у проведенні оцінки за такими показниками, як період напіввиведення, площа під кривою, кліренс і відновлення активності ФЗК. Відомо, що при внутрішньовенному введенні FVIII 1 Од./кг приводить до підвищення активності FVIII у сироватці крові на 2\%, відповідно введення 40 Од./кг FVIII призведе до підвищення активності FVIII у сироватці крові до 80\% - пікова активність фактора (нормальна активність FVIII 50-150\%) [13]. Під піковою активністю фактора розуміють момент, коли фактор досягає своєї найвищої активності - так званої пікової концентрації. Після певного періоду активність фактора буде знижена на 50\% від початкового обсягу; цей період має назву період напіврозпаду. Далі концентрація фактора у сироватці крові буде поступово знижуватися і досягне мінімальної (рис. 1). Нормальним вважають рівень активності ФЗК 50-150\%, відповідно введення концентрату ФЗК приводить до конверсії гемофілії в нормальний гемостаз. Так, при піковій концентрації FVIII наявний нормальний гемостаз, далі - зі зниженням активності фактора гемофілія повертається в легку, середньої тяжкості та тяжку форму (рис. 2). Оскільки рівень залишкової активносTi FVIII напряму пов'язаний із ризиком виникнення спонтанних кровотеч, необхідний контроль рівня ФК профілю пацієнта.

Аналіз фармакокінетики ФЗК включає:

- зміни активності FVIII, пов'язані з часом, після внутрішньовенної ін'єкції однієї дози FVIII:

- пікову концентрацію;

- мінімальну концентрацію;

- період напіввиведення $\left(\mathrm{t}_{1 / 2}\right)$;

- час до $1 \%$.

- інструменти: додатки WAPPS-Hemo, myPKFIT.

myPKFIT - програмне забезпечення на основі web-додатка, розроблене для пацієнтів, які отримують октоког альфа, та дозволяє моделювати режим дозування з урахуванням фармакокінетики профілю індивідуально для кожного пацієнта на підставі визначення активності FVIII [14]. Враховуючи те, що всі пацієнти різні, відповідно мінімальний рівень активності фактора індивідуальний для кожного. У 2017 р. розроблені порогові рекомендації щодо мінімальної концентрації ФЗК (табл. 3).

Завершуючи доповідь, Т. Урасіньскі детально зупинився на власному досвіді профілактичної терапії у польських хлопчиків із тяжкою гемофілією А. Відповідно до проведеного дослідження, діти з тяжкою формою гемофілії $A \in$ гетерогенною групою і при їх менеджменті застосування індивідуалізованого підходу з урахуванням фармакокінетики FVIII $\epsilon$ корисною стратегією лікування. Таким чином, індивідуалізований підхід до терапії пацієнтів із гемофілією дає можливість адаптувати режим лікування з урахуванням індивідуальних характеристик з метою зниження ризику кровотеч [16]. 
Рисунок 1 Фармакокінетика ФЗК

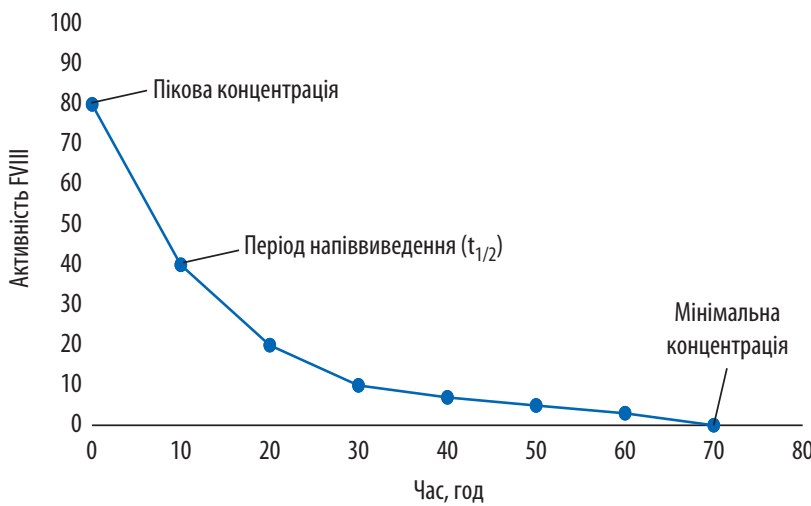

Рисунок 2 Конверсія гемофілії в нормальний гемостаз

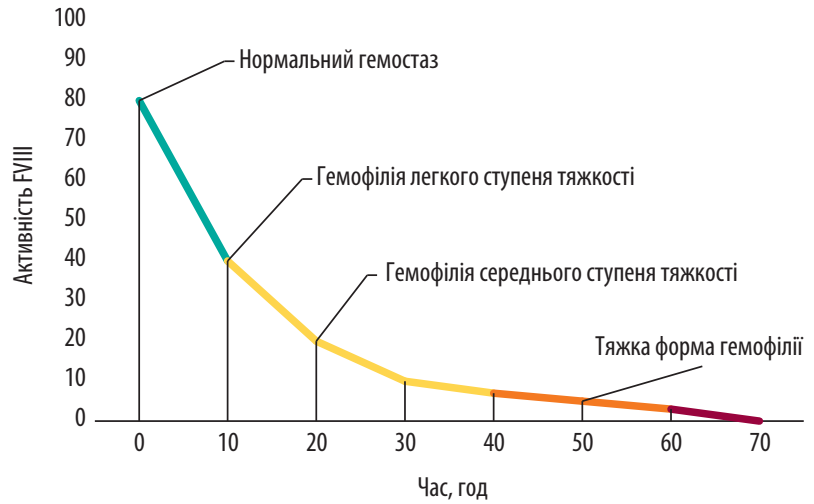

Таблиця 3 Порогові рекомендації щодо мінімальної концентрації Ф3К [15]

\begin{tabular}{ll}
\hline \multicolumn{1}{c}{ Рекомендації } \\
\hline $\begin{array}{l}\text { Рівень концентрації Ф3К, } \\
\%\end{array}$ & \multicolumn{1}{c}{ Категорія пацієнтів } \\
\hline$<1$ & Усі діти до моменту першої кровотечі \\
\hline $1-3$ & $\begin{array}{l}\text { Усі діти віком <2 років або всі діти, які ведуть малоактив- } \\
\text { ний («сидячий») спосіб життя }\end{array}$ \\
\hline $3-5$ & Діти груп первинної профілактики \\
\hline $5-15$ & $\begin{array}{l}\text { Діти, які займаються фізичною активністю, групи «високого } \\
\text { ризику»* }\end{array}$ \\
\hline
\end{tabular}

*Фізичні заняття групи «високого ризику» за шкалою Національної асоціації гемофілії (The National Hemophilia Foundation).

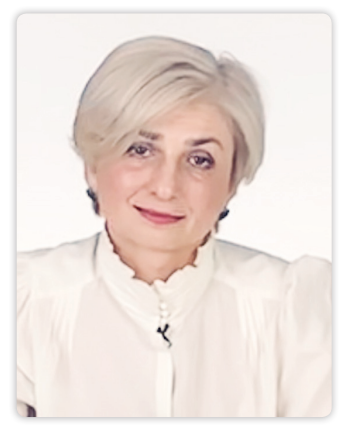

Олександра Стасишин у своїй доповіді висвітлила тему ефективності та безпеки застосування рекомбінантних факторів пролонгованої дії. Сьогодні гемофілія А становить близько половини усіх випадків клінічно діагностованих коагулопатій в усьому світі, її частота - 6,6-12,8 на 100 тис. осіб. Основними викликами, з якими стикаються хворі на гемофілію, $\epsilon$ повторні кровотечі у суглоби і м'язи, які можуть призвести до серйозного прогресуючого ураження опорно-рухового апарату — гемофілічної артропатії (рис. 3). Ще одним викликом, пов'язаним із гемофілією, $є$ розвиток інтракраніальних кровотеч. Якщо раніше смертність хворих на гемофілію сягала 70\%, то з початком комерційної доступності FVIII смертність становить 20\%, при цьому ризик зростає відповідно до тяжкості гемофілії.

Сьогодні існує безліч факторів, які впливають на розвиток гемофілічної артропатії, і в літературі наявна значна кількість досліджень щодо можливого локального впливу на ці факто- ри, але жодне з них не підтверджено щодо ефективності та безпеки (табл. 4). Тож єдиним ефективним та безпечним методом запобігання розвитку ускладнень, пов'язаних із гемофілією, $\epsilon$ застосування профілактичної терапії, можливості якої дозволяють збільшити тривалість і якість життя пацієнтів. Дані літератури свідчать, що при правильно підібраному лікуванні тривалість життя людей із гемофілією зіставна з тривалістю життя осіб без гемофілії. Однак сучасні можливості медицини призвели до того, що сьогодні на гемофілію страждає не лише молодь, а й пацієнти старшої вікової категорії, що, відповідно, пов'язано із проблемами, характерними для старіння. Так, пацієнти з гемофілією, порівняно зі своїми однолітками без гемофілії, мають більшу кількість супутніх захворювань та проблем у повсякденному житті, включаючи проблеми рухливості, ризик падінь, депресії. Крім того, незважаючи на оптимізацію профілактичної терапії, занадто багато пацієнтів і досі мають кровотечі, що впливає на якість їхнього життя та має згубний вплив на довгострокове здоров'я суглобів. Тому сучасні дослідження спрямовані на постійне вдосконалення профілактичного лікування гемофілії.

Далі спікер детально зупинилася на ефективності та безпеці застосування сучасних препаратів у профілактичній терапії пацієнтів із гемофілією. Інноваційні розробки та постійне удосконалення препаратів для лікування гемофілії А значно покращили сьогоднішні стандарти лікування. І, якщо раніше всі зусилля

Рисунок 3 Патогенез розвитку деформуючої артропатії [17]

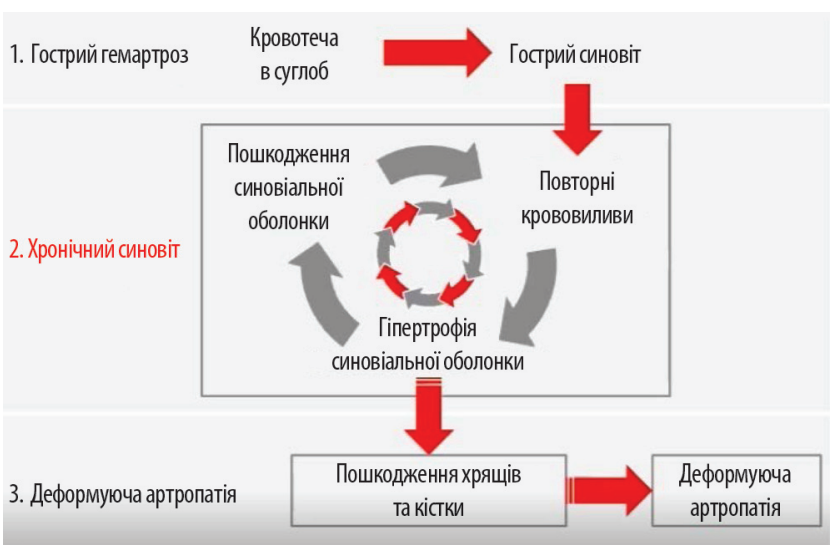

Таблиця 4 Фактори, що впливають на розвиток гемофілічної артропатії [18]

\begin{tabular}{|c|c|}
\hline \multicolumn{2}{|c|}{ Фактори, які провокують розвиток гемофілічної артропаті } \\
\hline Категорія & Фактори \\
\hline Білки заліза & $\begin{array}{l}\text { · Гемоглобін } \\
\text { • гемосидерин }\end{array}$ \\
\hline Ензими & $\begin{array}{l}\text { - Тромбін } \\
\text { - триптаза } \\
\text { - еластаза } \\
\text { - катепсин } \\
\text { - активність, що знижуєппотеоглікани }\end{array}$ \\
\hline Цитокіни & 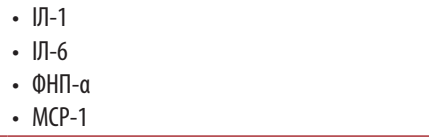 \\
\hline Фактори росту & $\begin{array}{l}\text { - VEGF } \\
\text { - PDGF }\end{array}$ \\
\hline Клітини & $\begin{array}{l}\text { - Еритроцити } \\
\text { - лейкоцити } \\
\text { - моноцити } \\
\text { - макрофаги } \\
\text { - Т-клітини } \\
\text { - тромбоцити }\end{array}$ \\
\hline
\end{tabular}

ІЛ - інтерлейкін; ФНП- - - фактор некрозу пухлини-а; МСР-1 - моноцитарний хемотаксический фактор-1; VEGF — фактор росту ендотелію судин; PDGF — тромбоцитарний фактор росту. 
були спрямовані на удосконалення препаратів ФЗК, то сьогодні розробки стосуються і плазмових, і рекомбінантних препаратів. Історія застосування рекомбінантного FVIII (rFVIII) починає свій відлік із 1992 р., коли на фармацевтичний ринок вперше вийшов рекомбінантний препарат ФЗК. Однак на цьому дослідники не зупинились, і в 2003 р. представлений удосконалений препарат rFVIII без додавання екзогенних білків людського/тваринного походження, що унеможливлювало розвиток алергічних реакцій. Сьогодні ефективність та безпека rFVIII підтверджена низкою досліджень. Так, результати нещодавно проведеного метааналізу п'яти досліджень PASS, мета якого - вивчити імуногенність та ефективність тривалої терапії препаратом rFVIII в реальній клінічній практиці, продемонстрували, що застосування rFVIII $\epsilon$ ефективною стратегією профілактичної терапії та асоційоване з низьким ризиком розвитку інгібіторів у пацієнтів із тяжкою та середньої тяжкості формами гемофілії [19].

Сучасним напрямком удосконалення профілактичного лікування $\epsilon$ застосування препаратів із подовженим періодом напіввиведення. У 2015 р. методом пегіляції виготовлено перший пролонгований препарат - пегільований rFVIII. Додавання поліетиленгліколю (ПЕГ) до рекомбінантного FVIII (ПЕГілювання) забезпечує пролонговану дію препарату і триваліший період напіввиведення (14-16год), що дозволяє суттєво зменшити кратність внутрішньовенного введення препарату. Механізм пролонгованої дії полягає в тому, що ПЕГ оточує FVIII та зменшує його зв'язування з фізіологічним рецептором кліренсу. Крім того, завдяки сучасній рекомбінантній технології у процесі посіву культури, на етапі очищення і кінцевого приготування рецептури, у препарат не додаються екзогенні білки людського/ тваринного походження, що нівелює можливість алергічних реакцій та повністю виключає можливість будь-якого інфікування. Одним із представників пегільованих препаратів $\epsilon$ руріоктоког альфа пегільований - пегільована молекула, що вбудована на кінці октокогу альфа з подовженим періодом напіввиведення в 1,3-1,5 раза порівняно $з$ дією октокогу альфа [20]. Персоналізована профілактика за допомогою додатка myPKFіТ може використовуватися і у пацієнтів, які отримують руріоктоког альфа пегільований. Результати багатоцентрового відкритого проспективного дослідження $(n=120)$ продемонстрували, що на фоні терапії руріоктоког альфа спостерігалася значно менша річна кількість кровотеч у пацієнтів, які перебували на профілактичному лікуванні порівняно з лікуванням «за вимогою». Також результати продемонстрували, що пегілювання знижує імуногенність рекомбінантного FVIII, при застосуванні руріоктокогу альфа пегільованого 2 рази на тиждень упродовж 6 міс із профілактичною метою не виявлено розвитку інгібіторів до FVIII [21].

Таким чином, сьогодні індивідуалізований (персоналізований) підхід до лікування набуває все більшого значення при менеджменті пацієнтів не лише з гемофілією, а й з іншими захворюваннями. Персоналізація має певні особливості щодо менеджменту пацієнтів, включно з оцінкою особливостей кожного індивідуально, наявністю прогностичних та хворобоасоційованих параметрів у пацієнтів, наявністю/відсутністю лікарських засобів та інструментів, які дозволяють призначати ці лікарські засоби пацієнтам із гемофілією А. Крім того, пандемія COVID-19 також внесла свої корективи у менеджмент паці$\epsilon$ нтів із гемофілією, що потребує нових заходів, спрямованих на зниження ризиків, асоційованих із коронавірусною інфекцією у пацієнтів із гемофілією. Сьогодні основною метою лікування пацієнтів із гемофілією $\epsilon$ не лише забезпечення тривалості, а й покращення якості життя пацієнтам цієї групи, одним з аспектів якого $\epsilon$ зменшення часу на організацію лікування та потреби у залученні медичних працівників. Індивідуалізований підхід сприятиме підвищенню прихильності пацієнта до терапії та дозволить контролювати перебіг захворювання $[22,23]$.

\section{Список використаної літератури/References:}

1. Vilchevskaya E. (2018) Hemophilia in Ukraine. Situational analysis based on unmet patient needs. Hematology. Transfusiology. Eastern Europe, 4(4): 456-465 (In Rus.).

2. Antunes S.V., Tangada S., Stasyshyn 0. et al. (2013) Randomized comparison of prophylaxis and on-demand regimens with FEIBA NF in the treatment of haemophilia $A$ and $B$ with inhibitors. Haemophilia, 20(1): 1-8.

3. Witmer C., Presley R., Kulkarni R. et al. (2011) Associations between intracranial haemorrhage and prescribed prophylaxis in a large cohort of haemophilia patients in the United States. Br. J. Haematol., 152(2): 211-216. doi: 10.1111/j.1365-2141.2010.08469.x.

4. Gringeri A., Ewenstein B., Reininger A. (2014) The burden of bleeding in haemophilia: is one bleed too many? Haemophilia, 20(4): 459-463. doi: 10.1111/hae.12375.

5. Funk M.B., Schmidt H., Becker S. et al. (2002) Modified magnetic resonance imaging score compared with orthopaedic and radiological scores for the evaluation of haemophilic arthropathy. Haemophilia, 8(2): 98-103. doi: 10.1046/j.1365-2516.2002.00585.x

6. Nilsson I.M., Hedner U., Ahlberg A. (1976) Haemophilia prophylaxis in Sweden. Acta Paediatr., 65(2): 129-135. https://doi.org/10.1111/j.1651-2227.1976.tb16525.x.

7. Rodriguez N.I., Hoots W.K. (2010) Advances in hemophilia: experimental asp ects and therapy. Hematol. Oncol. Clin. North Am., 24(1): 181-198. doi: 10.1016/j. hoc.2009.11.003.

8. Manco-Johnson M.J., Abshire T.C., Shapiro A.D. et al. (2007) Prophylaxis versus episodic treatment to prevent joint disease in boys with severe hemophilia. N. Engl. J. Med., 357(6): 535-544. doi: 10.1056/NEJMoa067659.

9. Srivastava A., Santagostino E., Dougall A. et al. (2020) WFH Guidelines for the Management of Hemophilia, $3^{\text {rd }}$ ed.

10. Windyga J., Chojnowski K., Klukowska A. et al. (2016) Część I: Wytyczne postępowania w hemofilii A i B niepowikłanej inhibitorem czynnika VIII i IX (wydanie zaktualizowane) Part I: Guidelines on the management of Haemophilia A and B without factor VIII or IX inhibitors (updated edition). Acta Haematologica Polonica, 47(2): 86-114.

11. Gringeri A., Lundin B., von Mackensen S. et al. (2011) A randomized clinical trial of prophylaxis in children with hemophilia A (the ESPRIT Study). J Thromb Haemost;9(4):700-10. doi: 10.1111/j.1538-7836.2011.04214.x.

12. Reininger A.J., Chehadeh H.E. (2013) The principles of PK-tailored prophylaxis. Hamostaseologie, 33(Suppl. 1): S32-S35.

13. Stasishin 0.V. (2021) Individualized approach to factor therapy of hemophilia: possibilities of modern technologies. Ukr. Med. J., 1(141): 1. D0l: 10.32471/umj.1680-3051.141.197253 (In Ukr.).

14. Álvarez-Román M.T., Fernandez-Bello I., de la Corte-Rodríguez H. et al. (2017) Experience of tailoring prophylaxis using factor VIII pharmacokinetic parameters estimated with myPKFiT ${ }^{\oplus}$ in patients with severe haemophilia A without inhibitors. Haemophilia, 23(1): e50-e54. doi: 10.1111/hae.13141.

15. Iorio A., Iserman E., Blanchette V. et al. (2017) Target plasma factor levels for personalized treatment in haemophilia: a Delphi consensus statement. Haemophilia, 23(3): e170-e179. doi: 10.1111/hae.13215. 10.

16. Urasinski T., Ociepa T., Badowska W. et al. (2019) Pharmacokinetics of Octocog a in Severe Hemophilia A Boys Aged Less than Six Years on Routine Prophylaxis. ISTH Congress, Melbourne.

17. Knobe K., Berntorp E. (2011) Haemophilia and joint disease: pathophysiology, evaluation, and management. J. Comorb., 1: 51-59. doi: 10.15256/joc.2011.1.2.

18. Valentino L.A. (2010) Blood-induced joint disease: the pathophysiology of hemophilic arthropathy. J. Thromb. Haemost., 8(9): 1895-1902. doi: 10.1111/j.1538-7836.2010.03962.x.

19. Iorio A., Marcucci M., Cheng J. et al. (2014) Patient data meta-analysis of Post-Authorization Safety Surveillance (PASS) studies of haemophilia A patients treated with rAHF-PFM. Haemophilia, 20(6): 777-783. doi: 10.1111/hae.12480.

20. Mullins E.S., Stasyshyn 0., Alvarez-Román M.T. et al. (2017) Extended half-life pegylated, full-length recombinant factor VIII for prophylaxis in children with severe haemophilia A. Haemophilia, 23(2): 238-246. doi: 10.1111/hae.13119.

21. Konkle B.A., Stasyshyn 0., Chowdary P. et al. (2015) Pegylated, full-length, recombinant factor VIII for prophylactic and on-demand treatment of severe hemophilia A. Blood, 126(9): 1078-1085. doi: 10.1182/blood-2015-03-630897.

22. Álvarez-Román M.T., Fernandez-Bello I., de la Corte-Rodríguez H. et al. (2017) Experience of tailoring prophylaxis using factor VIII pharmacokinetic parameters estimated with myPKFiT ${ }^{\odot}$ in patients with severe haemophilia A without inhibitors. Haemophilia, 23(1): e50-e54. doi: 10.1111/hae.13141

23. Carcao M., Srivastava A. (2016) FactorVIII/factor IX prophylaxis for severe hemophilia. Semin. Hematol., 53(1): 3-9. doi: 10.1053/j.seminhematol.2015.10.006. 